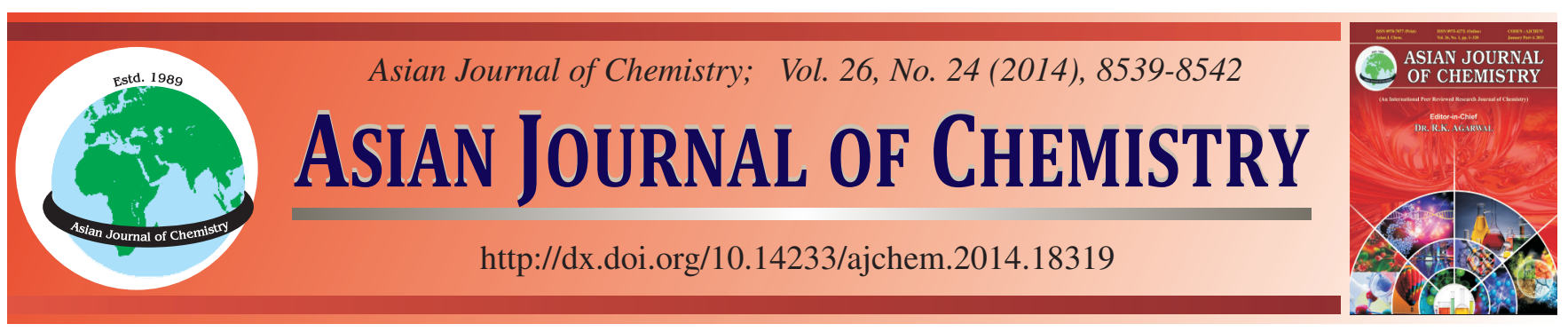

\title{
Highly Efficient Zinc Oxide Nanoparticles Catalyzed Green Synthesis of 1,5-Benzodiazepines under Solvent-Free Path
}

\author{
Yuhao Zhao ${ }^{1}$, Xuejie Yu ${ }^{2}$, Manpreet Saini ${ }^{3}$, YanXu MA ${ }^{4, *}$ and Rajesh K. Singh ${ }^{3, *}$
}

${ }^{1}$ School of Traditional Chinese Medicine, Capital Medical University, 100069 Beijing, P.R. China

${ }^{2}$ Beijing University of Chinese Medicine, 100029 Beijing, P.R. China

${ }^{3}$ Department of Pharmaceutical Chemistry, Shivalik College of Pharmacy, Nangal-140 126, India

${ }^{4}$ Department of Orthopedics, Beijing Traditional Chinese Medicine Hospital, Capital Medical University, Beijing 100010, P.R. China

*Corresponding authors: E-mail: rksingh244@gmail.com; yanxumabjtcm@126.com

Received: 13 June 2014;

Accepted: 4 September 2014;

Published online: 1 December 2014;

AJC-16398

\begin{abstract}
An efficient and simple environment-friendly method for the preparation of substituted 1,5-benzodiazepines as biologically interesting compounds under heterogenous catalyst is described. The one-pot multicomponent condensation of $o$-phenylene-diamine and substituted ketones catalyzed by zinc oxide nanoparticles (ZnO NPs) under microwave under solvent-free condition has been developed. The present protocol provides a green and improved pathway for the synthesis of 1,5-benzodiazepines in terms of excellent yields, short reaction times and reusability of catalyst.
\end{abstract}

Keywords: 1,5-Benzodiazepines, Zinc oxide nanoparticles, Heterogenous catalyst.

\section{INTRODUCTION}

Multicomponent coupling reaction (MCR) is one of the important and powerful green chemistry tools for the synthesis of wide varieties of biologically active medicinal compounds ${ }^{1,2}$. Another important aspect of green chemistry is the elimination of solvents in chemical processes or the replacement of hazardous solvents with relatively benign solvents. Some natural active constituents extracted from herbs such as polygala, platycladi seed and cortex albiziae have sedative effects, but the extracting process costs great energy and fund, and so an advanced synthesis is needed. Development of such multicomponent coupling reaction strategies under solvent-free condition has been of considerable interest, as they provide simple and rapid access to a large number of organic molecules through a sustainable path.

Benzodiazepines are widely used class of bioactive compounds that show interesting features, making them attractive targets for multicomponent coupling reactions. Among different types of the benzodiazepine class, 1,5-benzodiazepines are of particular interest as they belong to privileged medicinal scaffolds serving for the generation of medicinal compounds having pronounced central nervous system (CNS), antiinflammatory, antifeedant, antibacterial and analgesic activities $^{3-5}$. The current interest in 1,5-benzodiazepine derivatives arise from their potential application in the treatment of cancer, viral infection (on-nucleoside inhibitors of HIV-1 reverse transcriptase) and cardiovascular diseases ${ }^{6}$. Many of the methods reported for the synthesis of these compounds ${ }^{7-9}$ are associated with the minor limitations like tedious work up procedure, the necessity of neutralization of strong acidic media, producing undesired washes, long reaction times, unsatisfactory yields, require separation of the catalyst from the product and formation of side products.

Catalyst has played a vital role in the success of the chemical industry ${ }^{10}$. The use of transition-metal nanoparticles in catalysis is decisive as they mimic metal surface activation and catalysis at the nanoscale and thereby bring selectivity and efficiency to heterogeneous catalysis ${ }^{11}$. Among transitionmetal nanoparticles, zinc oxide nanoparticles ( $\mathrm{ZnO} N P s$ ) have been of considerable interest because of the role of $\mathrm{ZnO}$ in solar cells, catalysts, antibacterial materials, gas sensors, luminescent materials, and photocatalyst ${ }^{12}$. The recent literature survey reveals that $\mathrm{ZnO}$ nanoparticles as a heterogeneous catalyst has received considerable attention because it is inexpensive, nontoxic and environment-friendly properties ${ }^{13-17}$.

In continuation of our previous studies on exploration of various methods and catalysts in organic transformations ${ }^{18}$, herein, we report a highly efficient, green and solvent-free protocol for the one-pot multi-component synthesis of 1,5benzodiazepines using $\mathrm{ZnO}$ nanoparticles (Scheme-I). It is noteworthy that this work has none of the above-mentioned drawbacks at all. To the best of our knowledge, there is no report available in the literature describing the use of $\mathrm{ZnO}$ 
nanoparticles as catalysts for the synthesis of 1,5-benzodiazepines. The effectiveness of the process was studied by comparing the results obtained with and without catalyst under normal conditions.

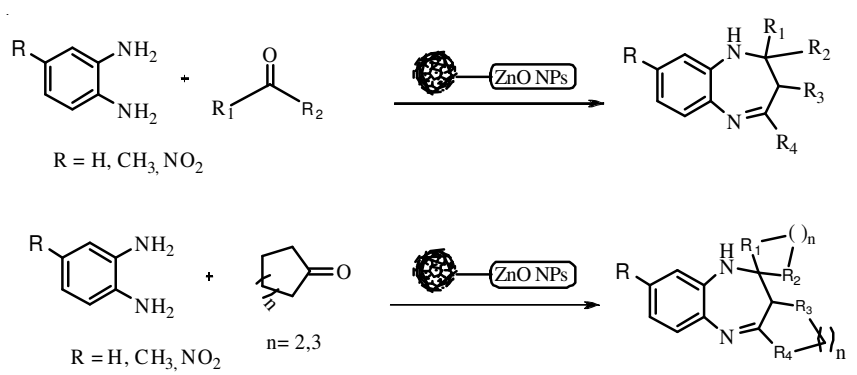

Scheme-I: Chemical reaction for the synthesis of 2,3-dihydro- $1 \mathrm{H}-1,5$ benzodiazepines using zinc oxide nanoparticles

\section{EXPERIMENTAL}

The melting points were determined on Veego-programmable melting point apparatus (microprocessor based) and are uncorrected. Proton $\left({ }^{1} \mathrm{H}\right)$ nuclear magnetic resonance spectra were obtained using Brucker AC-400 F, $400 \mathrm{MHz}$ spectrometer and are reported in parts per million (ppm), downfield from tetramethylsilane (TMS) as internal standard Infrared (IR) spectra were obtained with Perkin Elmer 882 Spectrum and RXI, FT-IR model using potassium bromide pellets (in $\mathrm{cm}^{-1}$ ). Elemental analyses for $\mathrm{C}, \mathrm{H}$, and $\mathrm{N}$ were performed on PerkinElmer $2400 \mathrm{CHN}$ elemental analyzer. X-ray diffraction of nanoparticles were obtained using X-ray diffractometer, Panlytical $\mathrm{X}^{\prime}$ pert Pro and $\left(\mathrm{CuK}_{\alpha}\right)$ radiations were used. TEM images were obtained from Transmission Electron Microscope, Hitachi H-7500 with $0.204 \mathrm{~nm}$ resolution and 6,00,000X magnification. Reactions were monitored and the homogeneity of the products was checked by TLC, which were prepared with silica gel $\mathrm{G}$ and activated at $110{ }^{\circ} \mathrm{C}$ for $0.5 \mathrm{~h}$. The plates were developed by exposure to iodine vapours. Anhydrous sodium sulphate was used as a drying agent.

Synthesis of $\mathrm{ZnO}$ nanoparticles: Zinc oxide nanoparticles are prepared according to the literature method with some modifications ${ }^{19}$. Zinc acetate $(9.10 \mathrm{~g}, 0.05 \mathrm{~mol})$ and oxalic acid $(5.4 \mathrm{~g}, 0.06 \mathrm{~mol})$ were combined by grinding in a mortar for $1 \mathrm{~h}$ at room temperature. The formed $\mathrm{ZnC}_{2} \mathrm{O}_{4} \cdot 2 \mathrm{H}_{2} \mathrm{O}$ nanoparticles were subjected to microwave irradiation at $150 \mathrm{~W}$ microwave power for $20 \mathrm{~min}$ to produced $\mathrm{ZnO}$ nanoparticles under thermal decomposition conditions (yield: $75 \%$ ).

General procedure for the preparation of 2,3-dihydro1H-1,5-benzodiazepines: $o$-Phenylenediamine ( $1 \mathrm{mmole})$ and $\mathrm{ZnO}$ nanoparticles (20 mol \% or 0.2 mmole) were crushed in mortar and pestle to a fine powder and transferred to a china dish and various ketone ( 2.2 mmole) was added. The reaction mixture was heated on oil bath for 40-60 min with occasional stirring. After completion of the reaction (monitored by TLC), the reaction mixture was cooled to room temperature and ethyl acetate was added. The catalyst was insoluble in ethyl acetate and it could therefore be separated by a simple filtration. The filtrate was collected, dried and residue was recrystallized from ethanol or subjected to column chromatography to get the pure products.
2,3-Dihydro-2-methyl-2,4-diphenyl-1H-1,5-benzodiazepine: (entry 1) IR (KBr, $\left.v_{\max }, \mathrm{cm}^{-1}\right): 3277$ ( $\left.\sec \mathrm{N}-\mathrm{H}\right), 3061$ (aromatic C-H), 2972 (aliphatic $\mathrm{C}-\mathrm{H}$ ), 1559 (aromatic $\mathrm{C}=\mathrm{C}$ ); ${ }^{1} \mathrm{H}$ NMR $\left(\mathrm{CDCl}_{3}\right): \delta 1.8\left(\mathrm{~s}, 3 \mathrm{H},-\mathrm{CH}_{3}\right), \delta 3.1(\mathrm{~d}, 1 \mathrm{H},-\mathrm{CH}), \delta$ $3.2(\mathrm{~d}, 1 \mathrm{H},-\mathrm{CH}), \delta$ 6.8-7.7 (m, 14H, ArH); Anal. Calcd. for $\mathrm{C}_{22} \mathrm{H}_{20} \mathrm{~N}_{2}$ : C, 84.58; H, 6.45; N, 8.97; found: C, 84.60; H, 6.42; N, 8.94.

2,2,4-Trimethyl-2,3-dihydro-1H-1,5-benzodiazepine: (entry 3) IR (KBr, $\left.v_{\max }, \mathrm{cm}^{-1}\right): 3292(\mathrm{NH}), 2955$ (aromatic $\mathrm{CH}$ ), 1632 (alkene $\mathrm{C}=\mathrm{C}$ ), 1474 (aromatic $\mathrm{C}=\mathrm{C}$ ); ${ }^{1} \mathrm{H} \mathrm{NMR}\left(\mathrm{CDCl}_{3}\right)$ : $\delta 1.3\left(\mathrm{~s}, 6 \mathrm{H},-\mathrm{C}\left(\mathrm{CH}_{3}\right)_{2}\right), \delta 2.2\left(\mathrm{~s}, 2 \mathrm{H},-\mathrm{CH}_{2}\right), \delta 2.4(\mathrm{~s}, 3 \mathrm{H}$, $\left.-\mathrm{CH}_{3}\right), \delta$ 6.7-7.2 (m, 4H, ArH); Anal. Calcd. for $\mathrm{C}_{12} \mathrm{H}_{16} \mathrm{~N}_{2}$ : C, 76.55; H, 8.57; N, 14.88; found: C, 76.51; H, 8.52; N, 14.92 .

10-Spirocycloheptan-6,7,8,9,10,10a,11,12-octahydrobenzo $[b]$ cyclohepta $[e][1,4]$ diazepine: (entry 6$) \mathrm{IR}\left(\mathrm{KBr}, \nu_{\max }\right.$, $\mathrm{cm}^{-1}$ ): 3328 (sec. NH), 3060 (aromatic CH), 2923 (alkene $\mathrm{CH}$ ), 2852 (alkane $\mathrm{CH}$ ), 1617 (imine $\mathrm{C}=\mathrm{N}$ ), 1493 (aromatic $\mathrm{C}=\mathrm{C}$ ). ${ }^{1} \mathrm{H}$ NMR $\left(\mathrm{CDCl}_{3}\right): \delta 1.5-2.4\left(\mathrm{~m}, 21 \mathrm{H},-\mathrm{CH}_{2},-\mathrm{NH}\right), \delta 2.6(\mathrm{~m}$, $\left.2 \mathrm{H},-\mathrm{CH}_{2}\right), \delta 2.8(\mathrm{~m}, 1 \mathrm{H},-\mathrm{CH}), \delta$ 6.6-7.4 (m, 4H, ArH); Anal. Calcd. for $\mathrm{C}_{20} \mathrm{H}_{28} \mathrm{~N}_{2}$ : C, 81.03; H, 9.52; N, 9.45; found: C, 81.15; H, 9.56; N, 9.54.

2,2,4-Trimethyl-2,3-dihydro-8-methyl-1H-1,5-benzodiazepine: (entry 7) IR ( $\left.\mathrm{KBr}, \mathrm{v}_{\max }, \mathrm{cm}^{-1}\right): 3454$ (sec. $\left.\mathrm{NH}\right), 2924$ (aromatic $\mathrm{CH}$ ), 2854 (alkane $\mathrm{CH}$ ), 1437 (aromatic $\mathrm{C}=\mathrm{C}$ ), 1237 (C-N), 946 (1,2,4-substituted oop); ${ }^{1} \mathrm{H}$ NMR $\left(\mathrm{CDCl}_{3}\right)$ : $\delta 1.2$ $\left(\mathrm{s}, 6 \mathrm{H},-\mathrm{CH}_{3}\right), \delta 1.35\left(\mathrm{~s}, 3 \mathrm{H},-\mathrm{CH}_{3}\right), \delta 2.3\left(\mathrm{~m}, 5 \mathrm{H},-\mathrm{CH}_{3},-\mathrm{CH}\right.$, -CH), $\delta 6.5$ (s, 1H, ArH), $\delta 6.79(\mathrm{~d}, 1 \mathrm{H}, J=7.4, \mathrm{ArH}), \delta 7.0(\mathrm{~d}$, $1 \mathrm{H}, J=8.7$, ArH); Anal. Calcd. for $\mathrm{C}_{13} \mathrm{H}_{18} \mathrm{~N}_{2}$ : C, 77.17; $\mathrm{H}$, 8.97; N, 13.85; found: C, 77.22; H, 8.91; N, 13.93 .

11-Spirocyclohexane-2,3,4,10,11,11a-hexahydro-8methyl-1H-dibenzo[b,e $][\mathbf{1 , 4}]$ diazepine: (entry 9) IR (KBr, $V_{\max }, \mathrm{cm}^{-1}$ ): 3351 (sec. NH), 2931 (alkene $\left.\mathrm{CH}\right), 2857$ (alkane $\mathrm{CH}$ ), 1633 (imine $\mathrm{C}=\mathrm{N}$ ), 1484 (aromatic $\mathrm{C}=\mathrm{C}$ ); ${ }^{1} \mathrm{H}$ NMR $\left(\mathrm{CDCl}_{3}\right): \delta 1.7-2.5\left(\mathrm{~m}, 18 \mathrm{H},-\mathrm{CH}_{2}\right), \delta 3.0\left(\mathrm{~s}, 3 \mathrm{H},-\mathrm{CH}_{3}\right), \delta 3(\mathrm{t}$, $1 \mathrm{H},-\mathrm{CH}), \delta$ 7.3-7.9 (m, 3H, ArH); Anal. Calcd. for $\mathrm{C}_{19} \mathrm{H}_{26} \mathrm{~N}_{2}$ : C, 80.80; H, 9.28; N, 9.92; found: C, 80.86; H, 9.34; N, 9.98 .

2,2,4-Trimethyl-2,3-dihydro-8-nitro- $1 H$-1,5-benzodiazepine: (entry 11) IR $\left(\mathrm{KBr}, \mathrm{v}_{\max }, \mathrm{cm}^{-1}\right)$ : $3280,1645,1600 .{ }^{1} \mathrm{H}$ NMR $\left(\mathrm{CDCl}_{3}\right), \delta$ ppm: $\delta 1.90(\mathrm{~s}, 6 \mathrm{H}), 2.95(\mathrm{~s}, 3 \mathrm{H}), 3.20(\mathrm{~s}$, 2H), 7.18 (s, 1H), 8.0-8.10 (m, 1H), 8.5-8.9 (m, 1H); Anal. Calcd. for $\mathrm{C}_{12} \mathrm{H}_{15} \mathrm{~N}_{3} \mathrm{O}_{2}$ : C, 61.78; H, 6.48; N, $18.01 \%$; found: C, 61.85; H, 6.66; N, $18.12 \%$.

\section{RESULTS AND DISCUSSION}

Initially we studied the influence of $\mathrm{ZnO}$ nanoparticles for the synthesis of 1,5-benzodiazepine using $o$-phenylenediammine and acetophenone as a model reaction and varying the amount of $\mathrm{ZnO}$ nanoparticles by simple optimization study (Table-1). The catalyst quantity was optimized to $20 \mathrm{~mol} \%$ of $\mathrm{ZnO}$ nanoparticles and excellent results (93\% yields) were achieved. Similarly, another 1,5-benzodiazepine derivatives have been synthesized from $o$-phenylenediamines and ketones in $85-93 \%$ yields (Table-2). It seems that high surface area and better dispersion of nanoparticles in the reaction mixture are reasons for better activities of $\mathrm{ZnO}$ nanoparticles. The catalytic activity of $\mathrm{ZnO}$ nanoparticles was evident when no product was obtained in the absence of the catalyst. 
TABLE-1

OPTIMIZATION OF CONCENTRATION OF ZINC OXIDE NANOPARTICLES FOR THE SYNTHESIS OF 2,3-DIHYDRO- $1 H-$ 1,5-BENZODIAZEPINES UNDER SOLVENT-FREE CONDITION ${ }^{a}$

\begin{tabular}{cccc}
\hline Entry & Amount of catalyst mol (\%) & Time (min) & Yield $^{\mathrm{b}}(\%)$ \\
\hline 1 & 5.0 & 60 & 78 \\
2 & 10.0 & 60 & 83 \\
3 & 15.0 & 60 & 88 \\
$4^{\mathrm{c}}$ & 20.0 & 60 & $93,90,85,85$ \\
5 & 25.0 & 60 & 93 \\
\hline
\end{tabular}

${ }^{a}$ Reaction conditions: $o$-phenylenediammine, acetophenone and catalyst; 'Isolated yields; ${ }^{\circ}$ Catalyst was recycled three times

To examine the reusability, the catalyst was recovered by filtration from the reaction mixture after dilution with ethyl acetate, washed with methanol, dried at $100{ }^{\circ} \mathrm{C}$ for $5 \mathrm{~h}$ and reused as such for the model reaction using $\mathrm{ZnO}$ nanoparticles (20\%) under optimized conditions (up to three cycles). It was observed that the yields of the product remained comparable in these experiments (Table 1, entry 4) which established the recyclability and reusability of the catalyst without any significant loss of activity.

In order to determine the catalytic behavior of $\mathrm{ZnO}$ nanoparticles, the possible mechanism of the reaction is shown in Scheme-II. To the best of our knowledge, $\mathrm{ZnO}$ nanoparticles catalyzed the reaction by the activations of both reactants through both Lewis acids $\left(\mathrm{Zn}^{2+}\right)$ and basic sites $\left(\mathrm{O}^{2-}\right)$. At one place, $\mathrm{ZnO}$ nanoparticles initiated electrophilic activation of the carbonyl groups of ketones by coordinated to oxygen through Lewis acid sites $\left(\mathrm{Zn}^{2+}\right)$ making them susceptible to nucleophilic attack by amines (activated by Lewis basic sites $\left(\mathrm{O}^{2-}\right)$ giving the intermediate diimine A. A 1,3-hydrogen shift of the attached methyl group then occurs to form an isomeric enamine $\mathrm{B}$, which cyclize to afford seven membered ring with the generation of catalyst.

The XRD pattern of $\mathrm{ZnO}$ nanoparticles is shown in Fig. 1. The particle size was calculated from X-ray diffraction images of $\mathrm{ZnO}$ nanoparticles using Scherrer formula as follows:

$$
\mathrm{d}=\frac{\mathrm{K} \lambda}{\beta \operatorname{Cos} \theta}
$$

where $d$ is the average particle size perpendicular to the reflecting planes, $\mathrm{K}$ is a grain shape dependent constant (0.9), $\lambda$ is the $X$-ray wavelength, $\beta$ is the full width at half maximum (FWHM), and $\theta$ is the diffraction angle. The average size of $\mathrm{ZnO}$ nanoparticles obtained from the XRD is about $40 \mathrm{~nm}$, using the Scherrer formula.

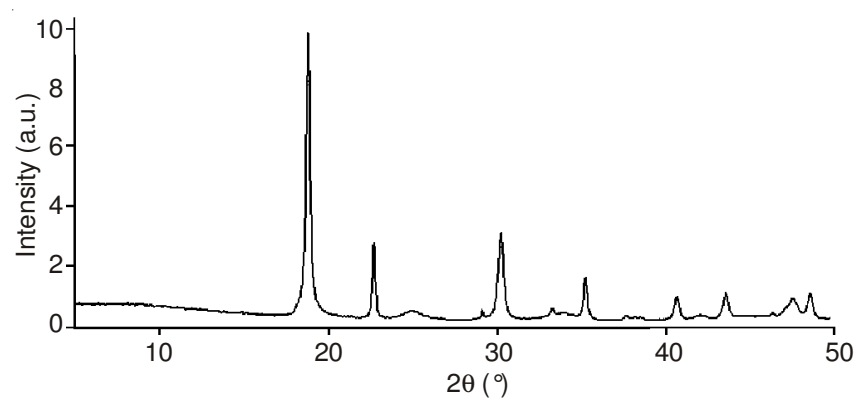

Fig. 1. XRD Pattern of $\mathrm{ZnO}$ nanoparticles

The TEM image of $\mathrm{ZnO}$ nanoparticles is shown in Fig. 2. As can be seen, the sample has a nanocrystalline structure with a spherical shape that were gained from zinc acetate and
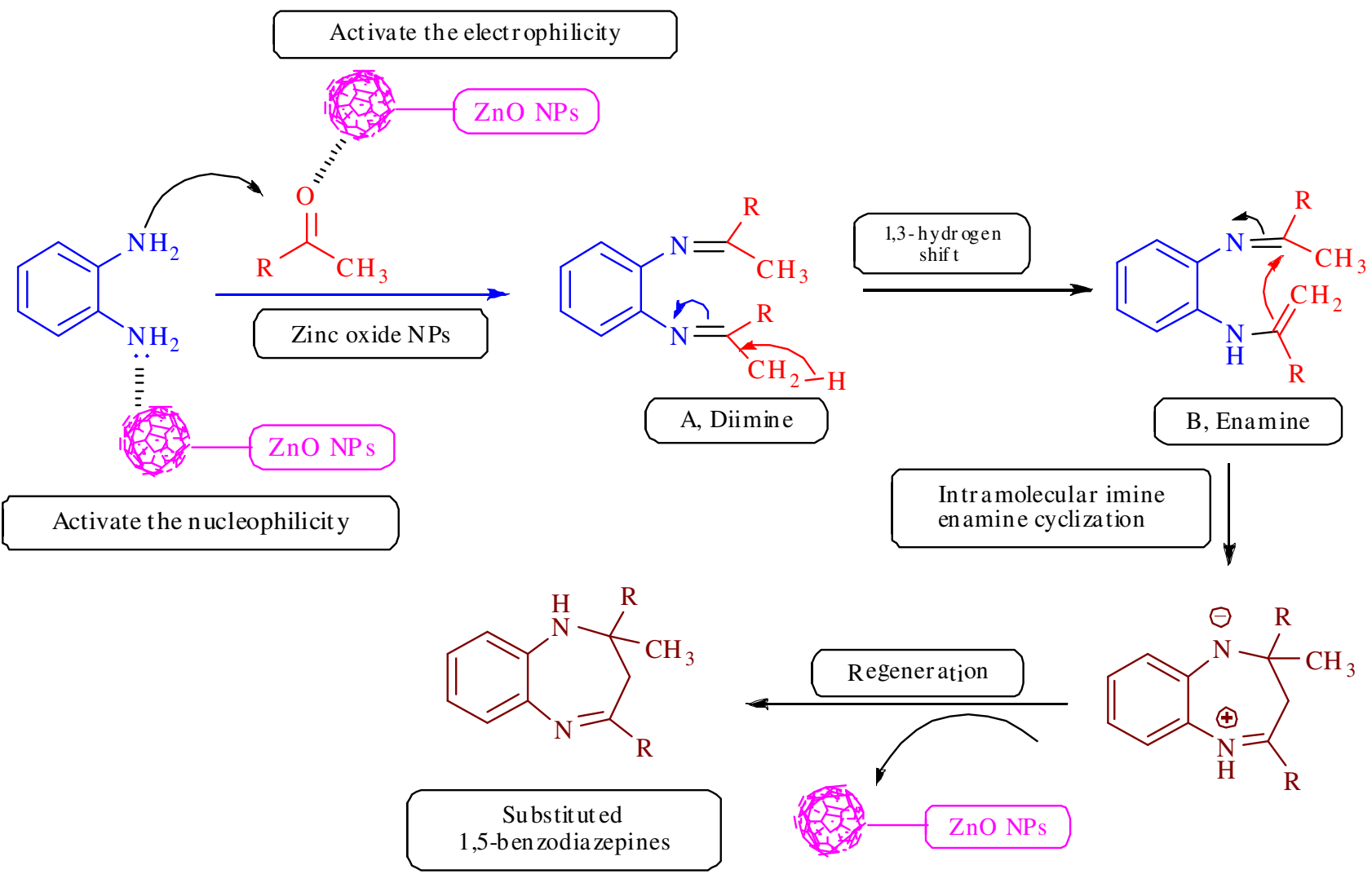

Scheme-II: Proposed mechanism and possible intermediates 
TABLE-2

CONDENSATION OF $o$-PHENYLENEDIAMINE WITH VARIOUS KETONES CATALYZED BY ZINC OXIDE NANOPARTICLES

\begin{tabular}{|c|c|c|c|c|c|c|c|c|c|}
\hline Entry & $\mathrm{R}$ & $\mathrm{R}_{1}$ & $\mathrm{R}_{2}$ & $\mathrm{R}_{3}$ & $\mathrm{R}_{4}$ & Yield (\%) & Time (min) & m.p. $\left({ }^{\circ} \mathrm{C}\right)$ & m.p. ${ }^{\text {lit }}\left({ }^{\circ} \mathrm{C}\right)$ \\
\hline 1 & $\mathrm{H}$ & $\mathrm{C}_{6} \mathrm{H}_{5}$ & $\mathrm{CH}_{3}$ & $\mathrm{H}$ & $\mathrm{C}_{6} \mathrm{H}_{5}$ & 93 & 60 & $149-150$ & $151-152^{10}$ \\
\hline 2 & $\mathrm{H}$ & $\mathrm{CH}_{3} \mathrm{C}_{6} \mathrm{H}_{5}$ & $\mathrm{CH}_{3}$ & $\mathrm{H}$ & $\mathrm{CH}_{3} \mathrm{C}_{6} \mathrm{H}_{5}$ & 89 & 50 & $97-99$ & $98-99^{6}$ \\
\hline 3 & $\mathrm{H}$ & $\mathrm{CH}_{3}$ & $\mathrm{CH}_{3}$ & $\mathrm{H}$ & $\mathrm{CH}_{3}$ & 90 & 40 & $138-139$ & $137-139^{10}$ \\
\hline 4 & $\mathrm{H}$ & $\mathrm{CH}_{3}$ & $\mathrm{C}_{2} \mathrm{H}_{5}$ & $\mathrm{H}$ & $\mathrm{CH}_{3}$ & 85 & 45 & $137-139$ & $137-138^{10}$ \\
\hline 5 & $\mathrm{H}$ & \multicolumn{2}{|c|}{$-\left(\mathrm{CH}_{2}\right)_{5^{-}}$} & \multicolumn{2}{|c|}{$-\left(\mathrm{CH}_{2}\right)_{4}^{-}$} & 88 & 40 & $137-138$ & $138-139^{11}$ \\
\hline 6 & $\mathrm{H}$ & \multicolumn{2}{|c|}{$-\left(\mathrm{CH}_{2}\right)_{6}^{-}$} & \multicolumn{2}{|c|}{$-\left(\mathrm{CH}_{2}\right)_{5^{-}}$} & 87 & 45 & $133-134$ & $136-139^{11}$ \\
\hline 7 & $\mathrm{CH}_{3}$ & $\mathrm{CH}_{3}$ & $\mathrm{CH}_{3}$ & $\mathrm{H}$ & $\mathrm{CH}_{3}$ & 90 & 50 & $126-128$ & $127-128^{11}$ \\
\hline 8 & $\mathrm{CH}_{3}$ & $\mathrm{C}_{6} \mathrm{H}_{5}$ & $\mathrm{CH}_{3}$ & $\mathrm{H}$ & $\mathrm{C}_{6} \mathrm{H}_{5}$ & 88 & 60 & $91-92$ & $92-93^{12}$ \\
\hline 9 & $\mathrm{CH}_{3}$ & \multicolumn{2}{|c|}{$-\left(\mathrm{CH}_{2}\right)_{5^{-}}$} & \multicolumn{2}{|c|}{$-\left(\mathrm{CH}_{2}\right)_{4^{-}}$} & 92 & 60 & $140-142$ & $142-143^{12}$ \\
\hline 10 & $\mathrm{CH}_{3}$ & \multicolumn{2}{|c|}{$-\left(\mathrm{CH}_{2}\right)_{6-}$} & \multicolumn{2}{|c|}{$-\left(\mathrm{CH}_{2}\right)_{5^{-}}$} & 88 & 55 & $121-122$ & $124-125^{12}$ \\
\hline 11 & $\mathrm{NO}_{2}$ & $\mathrm{CH}_{3}$ & $\mathrm{CH}_{3}$ & $\mathrm{H}$ & $\mathrm{CH}_{3}$ & 92 & 45 & $115-117$ & $114-116$ \\
\hline
\end{tabular}

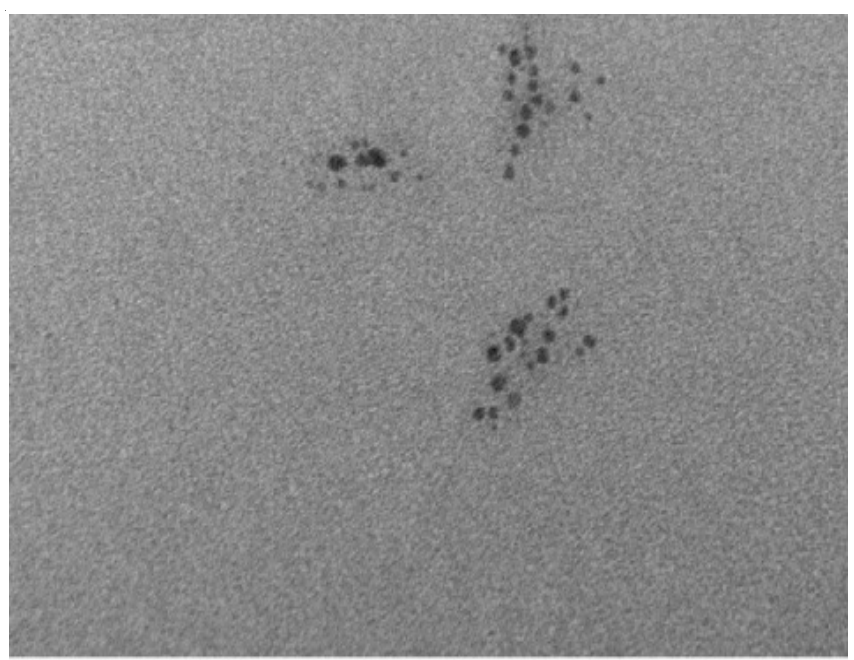

Fig. 2. TEM image of $\mathrm{ZnO}$ nanoparticles

oxalic acid with a particle size of about $40 \mathrm{~nm}$ under solutionfree mechanochemical conditions.

\section{Conclusion}

We have reported an efficient, inexpensive, non-hazardous ecofriendly procedure using a catalytic amount of $\mathrm{ZnO}$ nanoparticles under neat conditions. This method has several advantages, including high yield of products, short reaction time and easy experimental work-up. The reactivated catalyst can be reused for three consecutive cycles without any significant loss in catalytic activity.

\section{ACKNOWLEDGEMENTS}

The authors are thankful to Principal and Managing Committee, Shivalik College of Pharmacy, Nangal, India for providing the laboratory facilities. The authors are also thankful to Panjab University, Chandigarh, India for cooperation for spectral data. The Y.Z. and Y.M. thankful for research grant supported by Capital Application Project on Clinical Characteristics of Science and Technology Commission of Beijing
Municipalit (No. Z111107058811056); Planned Project on Beijing Traditional Chinese Medicine "inheritance of 3+3 programme" of Beijing Chinese Medicine Administration Bureau (2011-SZ-C-34).

\section{REFERENCES}

1. I. Ugi, Pure Appl. Chem., 73, 187 (2011).

2. D.J. Ramon and M. Yus, Angew. Chem. Int. Ed., 44, 1602 (2005).

3. L.O. Randall and B. Kappel, in eds.: S. Garattini, E. Mussini and L.O. Randall, Benzodiazepines, Raven Press: New York, p. 27 (1973).

4. H. Schutz, Benzodiazepines, Springer: Heidelberg (1982).

5. L.K. Landquist, Comprehensive Heterocyclic Chemistry, Pergamon: Oxford, vol. 1, p. 166 (1984).

6. R. Varala, R. Enugala and S.R. Adapa, J. Braz. Chem. Soc., 18, 291 (2007).

7. A.M. El-Sayed, A. Khodairy, H. Salah and H. Abdel-Ghany, Phosphorous Sulphur Silicon Rel. Elem., 182, 711 (2007).

8. X.-Q. Li and L.-Z. Wang, Chin. Chem. Lett., 25, 327 (2014).

9. S.S. Ilango, P.U. Remya and S. Ponnuswamy, Ind. J. Chem., 52B, 136 (2013).

10. J.H. Clark, Pure Appl. Chem., 73, 103 (2001).

11. H.H. Kung, Transition Metal Oxides: Surface Chemistry and Catalysis, Elsevier Science, New York, NY, USA, (1989).

12. C. Pacholski, A. Kornowski and H. Weller, Angew. Chem., 41, 1188 (2002).

13. F.M. Moghaddam, H. Saeidian, Z. Mirjafary and A. Sadeghi, J. Iranian Chem. Soc., 6, 317 (2009).

14. B.V. Kumar, H.S.B. Naik, D. Girija and B.V. Kumar, J. Chem. Sci., 123, 615 (2011).

15. M. Hosseini-Sarvari, J. Iranian Chem. Soc., 8(S1), S119 (2011).

16. I. Yavari and S. Beheshti, J. Iranian Chem. Soc., 8, 1030 (2011).

17. J. Safaei-Ghomi, M.A. Ghasemzadeh and S. Zahedi, J. Mex. Chem. Soc., 57, 1 (2013).

18. (a) R. Duvedi and R.K. Singh, Asian J. Chem., 24, 5665 (2012); (b) A. Sandhar, D.N. Prasad and R.K. Singh, Indian J. Heterocycl. Chem., 21, 369 (2012); (c) A. Sandhar, D.N. Prasad, A. Kapoor and R.K. Singh, Curr. Res. Chem., 4, 68 (2012).; (d) A. Sandhar and R.K. Singh, Asian J. Chem., 24, 5643 (2012); (e) S. Malik, S. Sharma and R.K. Singh, Asian J. Chem., 24, 5669 (2012); (f) P. Kaur, H. Sharma, R. Rana, D.N. Prasad and R.K. Singh, Asian J. Chem., 24, 5649 (2012); (g) Y. Zhao, S. Sharma, M. Huang, A. Kaur, R.K. Singh and Y. Ma, Asian J. Chem., 26, 5116 (2014); (h) T. Li, X. Zhai, D. Singh, R.K. Singh and X. Xu, Asian J. Chem., 26, 5207 (2014).

19. J. Safaei-Ghomi and M.A. Ghasemzadeh, Arab. J. Chem., doi:10.1016/ j.arabjc.2013.06.030. 